\title{
Development of community infrastructure through community forestry funds: what infrastructure gets priority?
}

\begin{abstract}
R.K. Pokharel ${ }^{1}$
Community forestry is a well established management form in Nepal. The success of community forestry in improving the forest condition encouraged the government to initiate some developmental works beyond the fulfillment of only basic forestry needs. This paper seeks to explore the investment made by CFUGs in community infrastructures and their priorities as well. Primary data from three mid-hill districts of Nepal were collected from questionnaire survey of $100 \mathrm{CFUGs}$. The results suggested that community infrastructure was the largest category of expenditures of CFUG funds wherein the majority of the CFUG accorded investment priority to schools. This paper concludes that higher CFUG income has led to a proportionately higher investment in community infrastructures and suggests that it was necessary to increase CFUG income to promote investment in community infrastructures. Investing CFUG funds on schools is a good harbinger of local development that contributes to the achievement of the Millennium Development Goal of universal primary education.
\end{abstract}

Key words: CFUG, CFUG funds, community forestry, community infrastructures

C ommunity forestry is a well established forest management form in Nepal (Pokharel, 2009). It is a major program of the Nepal government in the forestry sector and is being implemented throughout the country. As of October 2009, over one million hectares of forest lands were being managed by 14,439 Community Forest User Groups (CFUGs) involving 1.65 million households (DoF, 2009). In fact, nearly two-fifth of Nepal's households ${ }^{2}$ was involved in managing these forests.

Income generation is one of the major spin-offs of Nepal's community forestry. Community Forest User Groups (CFUG) earn income from the sale of forest products, membership fees and through fines levied from rule violators, and by renting out halls and utensils. The generated income need not be shared with the government so it accumulates within the CFUG funds. The annual income of the CFUGs in Nepal was estimated at NRs. 914 million (Kanel and Niraula, 2004). A recent study conducted by Pokharel (2008) also suggested that the average annual income of a CFUG was NRs. 63, 202. The generated fund requires investing 25 and 35 per cent of it in forest development and maintenance and pro-poor programs, respectively, but the remaining money can be used for whatever the community likes, depending on their needs and interests (MFSC, 2009).

The success of community forestry in improving the forest condition (Schreier et al., 1994; Virgo and Subba, 1994; Jackson et al., 1998; Tachibana et al., 2001; Gautam et al., 2002) encouraged the government to initiate some developmental works as it realized the potentiality of the community forestry to contribute to the national development. Such realization made the government decide on community forestry as a vehicle for rural development rather than limiting the community forestry only for the fulfillment of basic forestry needs. Consequently, many CFUGs started conducting different developmental works, including the construction of community infrastructures with their own funds.

For many donors such as the World Bank, community driven development is a growing area for making an investment. The concept of community driven development is being internalized by Nepal's community forestry. The communities in the community forestry known as CFUGs have an opportunity to choose projects through CFUG funds and also have control over its resources. This is

\footnotetext{
${ }^{1}$ Institute of Forestry Tribhuvan University, Nepal

${ }^{2}$ Total households of Nepal is 4,253,220 (NIDI, 2006)
} 


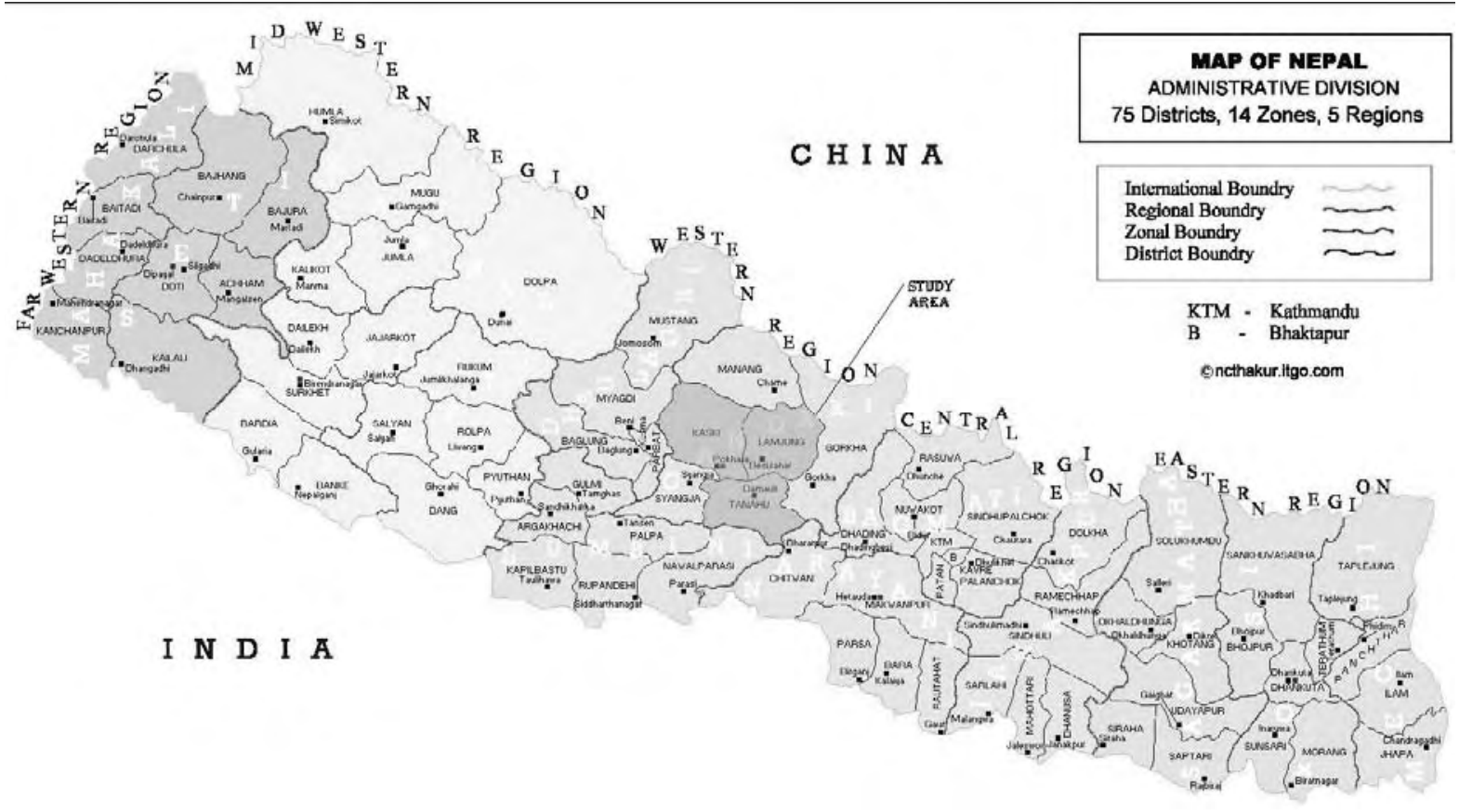

Fig 1 : Map of the study areas

community driven development as defined by a number of authors (Dongier et al., 2000; Narayan, 2002; Mansuri and Rao, 2004). In this context, this paper tries to explore the investment made by CFUGs in different community infrastructures and their priorities as well.

\section{Materials and methods}

\section{Study area and data collection}

This study covers three different mid-hill districts i.e. Lamjung, Tanahu, and Kaski of the Western Development Region of Nepal. These districts have been pioneers in the mid-hills where community forestry was initiated in the early 1980s. The total forest area in the study area is 211,561 hectares and one quarter of this had been handed over to CFUGs as community forestry. As of January 2007, over onequarter $(29 \%)$ of the CFUGs of the country were located in the Western Development Region; among them, over one-quarter (27\%) lies within this study area (DoF, 2009).

The CFUGs were classified into three categories depending on the information about fund size available at the District Forest Office. CFUGs with less than NRs. 20,000 were not included in this study as there was a general tendency in rural areas not to start financial activity with a common fund until it reached the size of NRs. 20,000 or more (Pokharel, 2008). CFUGs were then categorized into three groups based on the fund size: (1) NRs. 20, $000-$ NRs. 49, 999; (2) NRs. 50, 000 - NRs. 99, 999; and (3) NRs 100,000 and above. A total of 100 CFUGs were selected from three mid-hill districts 33 from each district i.e. Lamjung and Tanahu, and 34 from Kaski). A total of 11 CFUGs for each category of each district were selected randomly. An additional CFUG from the group of NRs 100, 000 and above of Kaski district was also selected randomly to fulfill the required number of CFUGs for this study. Information was gathered from the CFUGs through a structured questionnaire. The chairperson of the CFUG executive committee, the secretary and the treasurer were invited to a small meeting where the questionnaire was administered. The mean group size was 1.67 along with the standard deviation of 0.87 . This data was collected between April to November 2006.

\section{Results and discussion}

\section{CFUGs in three mid-hill districts in Nepal}

The CFUGs in the study districts were quite typical of what is found in this part of Nepal. Communities in this areas practiced subsistence farming, mostly depended on paddy, maize and forests. The forest per household in this area was 0.85 ha which is slightly higher than the national average of 0.73 ha (DoF, 2009). About $65 \%$ of the forests in this area was dominated by Sal (Shorea robusta), an important species for timber and valuable as well. The remaining (35\%) 
Table 1 : Basic characteristics of the sampled CFUGs $(n=100)$

\begin{tabular}{lcc}
\hline \multicolumn{1}{c}{ Basic characteristics } & Mean & Percentage \\
\hline Age of CFUGs (years) & 9.65 & \\
Number of households using community forests & 131.32 & 65 \\
Forest area (hectare) & 83.03 & 35 \\
Sal dominant forests in the study area & & 54 \\
Schima-Castanopsis dominant forest in the study area & & 28 \\
Households from advantaged group & & 18 \\
Households from disadvantaged group & & \\
Households from dalit group & & \\
\hline
\end{tabular}

of the forests was typical chilaune-katus (SchimaCastanopsis), and less valuable timber species (Table 1).

The average maturity of the CFUG in the study areas was 9.65 years. This suggests that they were relatively experienced in managing forest resources. Over onehalf $(54 \%)$ of the forest users households belonged to advantaged groups such as Brahmin, Chhetri and Newar, followed by disadvantaged groups such as Gurung, Tamang, and Magar (28\%) and dalits such as Damai, Kami, and Sarki (18\%). Dalits are members of occupational castes. They are generally disadvantaged in Nepal as compared to other castes such as Brahmin and Chhetri (Kunwar, 2003).

\section{Income from community forests}

Income generation is one of the important activities of the CFUGs in Nepal. This study measures the annual income to understand the income of CFUGs. The study defines income as the total amount generated by the CFUGs in a year from different sources such as selling of forest products, membership fees, and penalties. It calculates annual income as the total investment made by the CFUG over the last five years divided by five plus annual saving. From the questionnaire, the information on the current balance of the CFUGs account was obtained and the annual saving calculated as the current balance divided by the age of CFUG, i.e. number of years of CFUG formation. In the study areas, the average annual income of CFUGs and average annual saving was NRs. 63,202 and NRs. 11,629 respectively.

CFUGs Investment in Community Infrastructures Investments in this study refer to the total amount spent in a year for different activities. The CFUGs spent the generated income by deliberating on a project depending on their needs and interests. The CFUGs in the study areas had spent the generated income on many activities such as community infrastructures, pro-poor programs, and forest development works. This study focuses on investment made by CFUGs only on community infrastructures. The annual investment was estimated by assessing the CFUG investment. Annual investment was estimated as the total investment over the last five years divided by five. The average annual investment of a CFUG was NRs. 51,573.

In the study areas, over one-half (55\%) of the CFUG's investment was on community infrastructure which implies that CFUGs accorded highest priority to community infrastructures and invested their funds accordingly. Scholars (Dongol et al., 2002; Acharya 2003; Kanel and Niraula 2004; Pokharel 2008, 2009) have also observed that community infrastructures constituted the major allocation of CFUG funds' expenditures. The CFUGs on an average had spent NRs. 28,142 on community infrastructures annually. The CFUGs expenditures had gone to schools, temples, roads/trail construction, VDC/CFUG offices and community buildings, extending electricity/mills, water reservoirs/irrigation canals, grants to schools and support for teachers' salary. However, the most important expenditures were towards offices/community buildings, schools, and roads. We further disaggregated the annual expenditures of the community infrastructures to understand what percentage of the expenditure had gone into what activities and also what number of

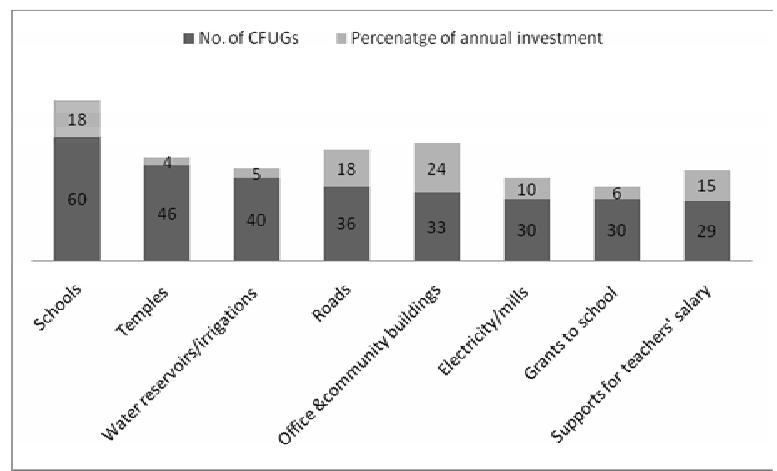

Fig 2 : Number of CFUGs and the percentage of annual investment in different community infrastructures 
CFUGs had made investments onto what activities. Figure 2 indicates that about one quarter (24\%) of the annual investment of community infrastructures had gone to office and community buildings. Similarly, about one fifth (18\%) of the annual investment of the community infrastructures had gone to schools and roads.

When we look at the number of the CFUGs contributing their income to CFUG office building, it appears that only one-third of the CFUGs had contributed part of the income to office and community buildings whereas three-fifth of the CFUGs allocated income to schools although this amount was less than on office and community buildings. Spending CFUG funds in school building is a good indicator of local development as it provides access to education. Similarly, about one-half (46\%) and two-fifth of the CFUGs had contributed part of the CFUG funds to temples and water reservoirs / irrigation canals, respectively, although the spent amount was small (Figure 2). Besides school buildings, the CFUGs also gave grants to schools and provided salary funds for school teachers. Over the past five years, the expenditures on schools, roads, and the water reservoirs/irrigation canals in the study area were NRs. 2.6 million, NRs. 2.5 million, and NRs. 667,000 respectively. Thus, the CFUGs had spent approximately NRs. 6 million on local infrastructures. The CFUGs had also provided a total amount of NRs. 804,055 and NRs. 1,998,300 as grants and salaries, respectively, over the last five years. Education and literacy are important factors for development. In many cases in Nepal, rural people do not receive public services due to a lack in basic infrastructures. There has been a tendency of some families to leave the village for urban areas, if it was affordable. The CFUGs expenditures in the community infrastructures would facilitate making the public service available at the village level and induce people to remain in the villages.

To better understand whether annual income size differs in the investment made in the community infrastructures, we classified annual incomes into three categories: up to NRs. 24,000, NRs. 24,001 to NRs. 52,000 and above NRs. 52,000. We ran ANOVA with annual income size and the CFUGs expenditure in different community infrastructures to understand the association between income categories and investment choices among the different community infrastructures. The ANOVA results suggested that the mean differences between the CFUG income size and expenditure in school buildings $(\mathrm{F}=8.323$; $\mathrm{p}<.000)$, roads $(\mathrm{F}=4.367 ; \mathrm{p}<.015)$, temples $(\mathrm{F}=3.058 ; \mathrm{p}<.052)$, office and community buildings $(\mathrm{F}=9.209 ; \mathrm{p}<.000)$, water reservoirs/irrigation canal $(\mathrm{F}=7.353 ; \mathrm{p}<.001)$, and grants to school $(\mathrm{F}=3.980 ; . \mathrm{p}<022)$ were statistically significant. The results also indicated that the CFUGs with higher income tended to spend the CFUG funds on schools, roads, temples, office and community buildings, water reservoirs/irrigation canals, and grants to schools. The CFUG income size did not make any differences over spending CFUG funds on salaries for school teachers.

\section{Decision making in CFUGs}

There are two tiers of organizational structures in CFUGs: General Assembly (GA) and Executive Committee (EC), also known as Community Forest User Group Committee (CFUGC). GA represents all members of the CFUGs and the EC is composed of some 9-15 persons, depending on the size of CFUGs. The EC members were either elected or unanimously nominated by the users as representatives. Generally, GA meets once a year during mid January to February and the EC meets about once a month. GA is invested with the mandate to make any decision related to forest management such as framing rules on forest use, decision on penalties for rule violators, fixing schedule for silvicultural operations, and managing generated funds with simple majority. However, there has been an increasing practice of EC decision-making, particularly over the use of CFUG funds.

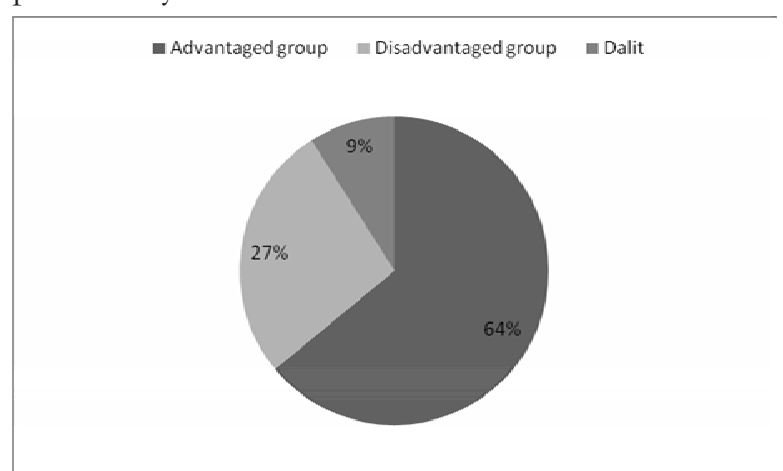

Fig 3 : Different groups representing in the executive committee

In the study areas, the average size of EC was 11 $( \pm 2)$ members. Overwhelmingly, the CFUGs had selected EC members through consensus and only a few $(4 \%)$ had election for the key posts such as chairperson and secretary. Over one quarter (27\%) 
of the EC members were female. Similarly, about twothirds of the members in the EC were from advantaged groups, followed by disadvantaged groups and dalits (Figure 3). This suggests that the CFUGC were inclusive in terms of representation from different groups. However, the advantaged group was likely to influence the decisions in their favour since the number of disadvantaged groups and dalits represented in the executive committee was low and also because they do not oppose decisions. Women and members from disadvantaged groups participated in the meetings passively as their numbers were low in the committee and because their opinions did not carry much weight in the decisions (Rasaily, 1996; Thapa et al., 1998). Several studies have commented on the membership of CFUGs and the related benefits favouring economically advantaged groups (Graner, 1999; Kanel and Varghese, 2000; Malla, 2000; Malla et al., 2003).

The CFUGs had generated substantial income from community forestry and spent the major part of the generated income on community infrastructures. CFUGs spent more than one-half of their income on community infrastructures, which were basic foundations for development. The CFUGs chose the projects themselves and implemented them accordingly. In the study areas, CFUGs had given first priority to education by supporting school building and this finding is different from the findings of Shrestha (2007). She had conducted a study on one of the mid-hill districts to investigate the local need and priority and had found that the first priority was motor roads. In this study area, however, the CFUGs seemed to be more concerned about education since three-fifth of the CFUGs had allocated part of their income to school buildings. They were also continuing to make the investments on school building as their fund grew and also provided grants to schools as well. Paying for the salaries of school teachers was not significantly correlated with the CFUG income size. The probable reason could be that people in the village realized the importance of education and that made the CFUGs spend the CFUG funds for paying salaries to school teachers - irrespective of the CFUG fund size. As many schools in the rural areas suffer from the lack of teachers because the fund available from the government was not good enough to pay the required teachers' salaries. Spending the CFUG funds on school is a good supplement for local development. Education and literacy are extremely important factors for development. Female literacy has been the foundational feature of Kerala's political culture and crucial in the creation of public opinion (Dreze and Sen, 1997; Sen, 1999).

We may argue that the decision to spend CFUG funds on schools was likely influenced by the advantaged groups since people in Nepal often made the argument that poor cannot afford to send their children to school so they may not accord school in their priority list. Spending the CFUG funds on schools provides an access to education as many people in Nepal's rural areas are illiterate because they did not have access to schools. Spending money on schools would benefit poor as well in the long run as poor in many cases were not getting key positions in the executive committees because of illiteracy. Foster and Rosenzweig (2003) conducted a study in India and argued that roads were pro-poor, irrigation investments were pro-rich and schools were neutral. Spending CFUG funds on schools would benefit not only the poor but also contribute to the achievement of Nepal's Millennium Development Goal of universal primary education. Nepal government has called for local and international commitment on "education for all".

\section{Conclusions}

The CFUGs are contributing to local economic development by allocating the generated income in various activities. Some form of infrastructure investment is a major category of expenditures of the CFUG income. The majority of CFUG expenditure was for the community infrastructures within the village. The CFUG expenditures in majority of the cases were going towards improving school infrastructures suggesting that CFUGs accorded school infrastructures as a priority which is considered a good harbinger for local development. Although Nepal government had made local and international commitment of education for all, it has not been able to expand the required number of schools into rural areas due to the paucity of resources. CFUGs priority investment on school building will help reduce the government burden to expand access to schools in the rural areas. There is an increasing trend of people moving into urban areas for education in Nepal so the CFUGs expenditure in education may induce the people to stay back in their villages. Moreover, the access to education also facilitates the achievement of the commitment of Nepal's government to education and also the Millennium Development Goal of universal primary education. 


\section{Acknowledgements}

Funding support from South Asia Network for Development and Environmental Economics (SANDEE) for conducting this study is greatly appreciated. The author would like to acknowledge the people from number of villages who participated in the research.

\section{References}

Acharya, K.P. 2003. Sustainability of support for community forestry in Nepal, Forests, Trees and Livelihoods 13: 247 - 260.

Department of Forests (DoF). 2009. Community Forest User Groups Database. Community Forestry Division, Department of Forests, Kathmandu.

Dongol, C.M., Hughey, K.F.D. and Bigsby, H.R. 2002. Capital formation and sustainable community forestry in Nepal, Mountain Research and Development 22 (1): $70-77$.

Dongier, P., Domelen, J., Ostrom, E., Ryan, A., Wakeman, W., Bebbington, A., Alkire, S. Esmail, T. and Polski, M. 2000. "Community Driven Development." In The Poverty Reduction Sourcebook, Chapter 9. Washington, D.C.: The World Bank.

Dreze J. and Sen, A. (eds.). 1997. Indian development - Selected regional perspective, Delhi: Oxford University Press.

Foster, A. and Rosenzweig, M. 2003. Democratization, Decentralization and the Distribution of Local Public Goods in a Poor Rural Economy. BREAD Working Paper No. 010.

Gautam, A.P., Webb, E.L. and Eiumnoh, A. 2002. GIS assessment of land use cover changes associated with community forestry implementation in the middle hills of Nepal, Mountain Research and Development 22 (1): 63 - 69.

Graner, E. 1999. Forest policies and access to forests in Nepal: Winners and losers. In Anthropology and sociology of Nepal: Culture, societies, ecology, and development, (eds.) Chhetri, R.B. and Gurung, O.P., Kathmandu: Sociological and Anthropological Society of Nepal (SASON), 212-224.

Jackson, W.L., Tamrakar, R.M., Hunt, S. and Shepherd, K.R. 1998. Land use changes in two middle hills districts of Nepal, Mountain Research and Development 18: $193-212$.

Kanel, K.R. and Niraula, D.R. 2004. Can rural livelihood be improved in Nepal through community forestry? Banako Jankari 14 (1): $19-26$.

Kanel, K. and Varghese, G. 2000. "Quantifying the benefits of community forestry in Nepal towards development of a participatory methodology of economic valuation", paper presented at $8^{\text {th }}$ biennial IASCP conference, Indiana University, USA.

Kunwar, K.B. 2003. The Himalayan Poverty Through Rural Development ( $1^{\text {st }}$ edition 2001), Kathmandu, Nepal: Meena Prakashan.

Malla, Y.B. 2000. Impact of community forestry policy on rural livelihoods and food security in Nepal, Unasylva 51 (3): 37 - 45.

Malla, Y.B., Neupane, H.R. and Branney, P. 2003. Why aren't poor people benefiting more from community forestry? Journal of Forests and Livelihood 3 (1): $78-93$.

Mansuri, G. and Rao, V. 2004. Community based and driven development: A critical review, The World Bank Research Observer 19 (1): 1 - 39.

MFSC. 2009. Directive for Community Forest Development Program. Ministry of Forests and Soil Conservation, Kathmandu, Nepal.

Narayan, D. 2002. Empowerment and Poverty Reduction: A Source Book, Poverty Reduction and Economic Management. Washington, D.C., USA: The World Bank.

Pokharel, R.K. 2008. Nepal's Community Forestry Funds: Do They Benefit the Poor? Working Paper No. 31-08, Kathmandu: South Asian Network for Development and Environmental Economics (SANDEE).

Pokharel, R.K. 2009. Pro-poor programs financed through Nepal's community forestry funds: Does income matter? Mountain Research and Development, 29 (1): $67-74$.

Rasaily, L. 1996. Benefit Sharing and Social and Institutional Decision Making Process within Selected Forest User Groups. Project report B/NUCKFP/33, Dhankuta, Nepal: Nepal-UK Community Forestry Project. 
Schreier, H., Brown, S., Schmidt, M., Shah, P., Shrestha, B., Nakarmi, G., Subba, K. and Wymann, S. 1994. Gaining forest but losing ground: A GIS evaluation in a Himalayan watershed, Environmental Management 18 (1): $139-150$.

Sen, A. 1999. Development as Freedom. Oxford University Press.

Shrestha, S. 2007. Basic infrastructure service planning for rural development: Understanding local need and priority, Nepalese Journal of Development and Rural Studies 4 (1): 83 - 91.

Tachibana, T., Upadhaya, H.K., Pokharel, R.K., Rayamajhi, S. and Otsuka, K. 2001. Common property forest management in the hills region of Nepal, In Land Tenure and Natural Resource Management: A Comparative Study of Agrarian Communities in Asia and Africa (eds.) Otsuka, K. and Place, F., Baltimore: The Johns Hopkins University Press, 273 - 314.

Thapa, S., Shrestha, R.N., Yadav, K.P. 1998. SocioEconomic Aspects of the Follow-up Forest Resource Assessment Study. Nepal-UK Community Forestry Project Report B/ NUKCFP/55, Kathmandu, Nepal.

Virgo, K.J. and Subba, K.J. 1994. Land use change between 1978 and 1990 in Dhankuta District, Eastern Nepal, Mountain Research and Development 14: $159-170$. 